\title{
СИСТЕМА СБАЛАНСИРОВАННЫХ ПОКАЗАТЕЛЕЙ ДЛЯ ОЦЕНКИ ДЕЯТЕЛЬНОСТИ ТУРИСТСКИХ ОРГАНИЗАЦИЙ
}

\author{
(C) 2021 Гизатуллина О.М. \\ кандидат экономических наук, доцент Департамента бизнес-аналитики \\ Финансовый университет при Правительстве Российской Федерации, Россия, Москва \\ E-mail: OMGizatullina@fa.ru
}

Туризм - одна из тех отраслей, которые из-за распространения вируса оказались в самом непростом положении. Поэтому в ожидании более благоприятных условий представителям сферы туризма необходимо сосредоточиться сейчас на сокращении издержек и увеличении каналов коммуникации с потенциальными потребителями услуг, выстраивание партнерской экосистемы с соседствующими организациями.

Ключевые слова: туризм, показатели оценки туристской деятельности, система сбалансированных показателей, устойчивое развитие.

Исходя из имеющегося потенциала туристской сферы Российской Федерации и комплексной поддержки со стороны государства можно сделать вывод, что данная сфера является значимой и после открытия границ получит новый импульс к развитию.

В настоящее время туристские фирмы рассчитывают огромное количество показателей, в то время как оценить эффективность деятельности турфирм можно с помощью небольшой группы принципиально важных показателей. Большой поток информации только затрудняет принятие эффективных управленческих решений. Для формирования системы показателей оценки эффективности туристской деятельно- сти рекомендуется использовать концепцию сбалансированных показателей Д.Нортона и Р. Каплана.

На рисунке 1 представлены основные принципы формирования системы сбалансированных показателей (ССП) для туристских фирм.

В тяжелых современных условиях функционирования туристской сфере необходима разработка новейших информационных возможностей и технологий сбора информационных данных.

Российским турфирмам рекомендуется использовать ССП как главную информационнообеспечивающую систему всех процессов управления.

охват основных аспектов функционирования компании и ключевых факторов успеха, которые необходимо учитывать при формировании стратегии организации

взаимосвязь показателей оценки ключевых аспектов функционирования туристских фирм

простота и обоснованность расчета индикаторов

сопоставимость данных и возможность сравнивать показатели

Puc. 1. Основные принципы формирования ССП 
Туристским фирмам рекомендуется сформировать ССП (рисунок 2), которая будет трансформирована в систему управления, для принятия на основе принципа сбалансированности показателей эффективных управленческих решений.

Разработка ССП осуществляется во взаимосвязи со стратегией туристской организации по основным аспектам ССП, должна содержать индикаторы, их целевые значения, порядок расчета, единицы измерения рисунок 3.

Главным аспектом при разработке системы сбалансированных показателей (ССП) является финансовый, так как главная цель любой коммерческой организации - это экономическая эффективность, поэтому уделяется повышенное внимание формированию и оценке финансовых индикаторов.

Разработанная система сбалансированных показателей включает четыре группы показателей, как показано в табице 1.

Сегодня туризм является одной из наиболее быстроразвивающихся сфер, которая обеспечивает значительную долю в ВВП, а также создает большое количество рабочих мест. Ту-

Puc. 2. ССП для туристских организаций

\section{Система \\ управления}

Разработать

стратегию и

миссию

Разработать

стратегическую

карту и довести ее

до всех

сотрудников

методы и

способы

реализации

турфирмы

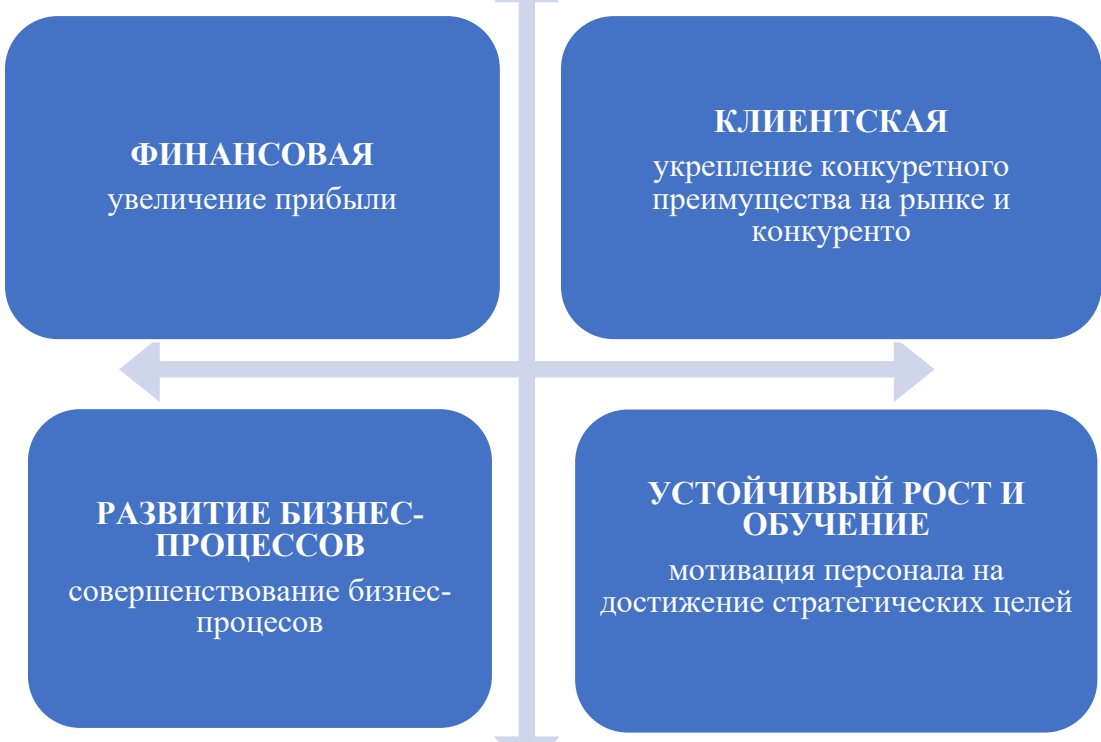

Рис. 3. Рекомендуемая стратегия развития турфирм 
Таблица 1. Система сбалансированных показателей для туристской сферы

\begin{tabular}{|c|c|c|}
\hline $\begin{array}{l}\text { Группы пока- } \\
\text { зателей }\end{array}$ & $\begin{array}{l}\text { Показатели, характеризующие эффектив- } \\
\text { ность туристских организаций (на микроу- } \\
\text { ровне) }\end{array}$ & $\begin{array}{l}\text { Показатели, характеризующие состояние } \\
\text { туристского рынка и вклад туризма в нац. } \\
\text { экономику } \\
\text { (на макроуровне) }\end{array}$ \\
\hline $\begin{array}{l}\text { 1. Финансо- } \\
\text { вые показа- } \\
\text { тели }\end{array}$ & $\begin{array}{l}\text { - выручка от реализации туристского про- } \\
\text { дукта } \\
\text { - комиссионные, агентские и другие возна- } \\
\text { граждения } \\
\text { - сумма средств, перечисленных поставщи- } \\
\text { кам туристского продукта } \\
\text { - прибыль (убыток) }\end{array}$ & $\begin{array}{l}\text { - объем туристского потока } \\
\text { - общая величина туристских расходов } \\
\text { - доля туризма в ВВП } \\
\text { - количество санаторно-курортных организа- } \\
\text { ций }\end{array}$ \\
\hline $\begin{array}{l}\text { П. Показа- } \\
\text { тели для } \\
\text { анализа } \\
\text { конкурент- } \\
\text { ных позиций } \\
\text { на рынке } \\
\text { туризма }\end{array}$ & $\begin{array}{l}\text { - объем туристского потока } \\
\text { - расширение ассортимента предоставляе- } \\
\text { мых туристских услуг }\end{array}$ & $\begin{array}{l}\text { - показатели туристского потока (число при- } \\
\text { бытий, количество прибытий) } \\
\text { - состояние материально-технической базы } \\
\text { - показатели развития международного } \\
\text { туризма }\end{array}$ \\
\hline $\begin{array}{l}\text { 3. Показате- } \\
\text { ли оценки } \\
\text { бизнес- } \\
\text { процессов }\end{array}$ & $\begin{array}{l}\text { - повышение квалификации сотрудников } \\
\text { - внедрение современных информационных } \\
\text { технологий, в том числе электронная путевка } \\
\text { - совершенствование внутри организации } \\
\text { бизнес-процессов }\end{array}$ & $\begin{array}{l}\text { Внедрение современных информационных } \\
\text { технологий } \\
\text { - гибкая методология разработки программ- } \\
\text { ного продукта Agile/DevOps } \\
\text { - искусственный интеллект/ предиктивный } \\
\text { - система блокчейн } \\
\text { - программы по обработке больших данных } \\
\text { - интернет вещей }\end{array}$ \\
\hline $\begin{array}{l}\text { 4. Показате- } \\
\text { ли оценки } \\
\text { системы } \\
\text { мотивации }\end{array}$ & Оценка системы мотивации персонала & $\begin{array}{l}\text { Внедрение концепции устойчивого развития } \\
\text { туризма }\end{array}$ \\
\hline
\end{tabular}

ризм оказывает влияние на различные сектора экономики, в том числе транспорт, связь и другие, выступая в роли катализатора социальноэкономического развития страны.

В современных условиях распространения COVID-19 внедрение концепции устойчивого развития стало наиболее актуальным, особенно в туристской деятельности. «Под устойчивым развитием туризма понимается такое развитие, которое создает условия для туризма и отдыха всех слоев населения, сохранения качества среды обитания и роста социально-экономического благополучия» [1].

Туризм в узком смысле напрямую связан с сохранением жизни и здоровья, а также с охраной окружающей среды, в широком же смысле, концепция устойчивого развития должна распространяться на все сферы жизнедеятельности. Концепция устойчивого развития должна встать во главе развития туризма, так как природная среда составляет основную часть ресурсной базы туризма.

При разработке инструментов развития индустрии туризма необходимо соблюдать прин- ципы устойчивого развития.

«В 1996 году Комиссией по устойчивому развитию ООН была разработана первая комплексная система индикаторов устойчивого развития туризма, которая содержала четыре группы индикаторов: социальные (41), экономические (26), экологические (55), организационные (10).

В настоящее время уровень развития туризма оценивается на основе международных рейтингов по уровню развития туризма.

Наибольшее признание получил международный рейтинг под названием «Индекс конкурентоспособности туризма», созданный Центром по глобальной конкурентоспособности и эффективности при Всемирном экономическом форуме (г. Давос). В оценке индекса конкурентоспособности туризма используется 75 индикаторов, объединенных в 14 групп, характеризующих различные аспекты развития туризма, в том числе и социально-экономические» [1].

Предложим критерии оценки устойчивого развития в сфере туризма, как показано в таблице 2. . 


\section{Таблица 2. Индикаторы устойчивого развития туризма}

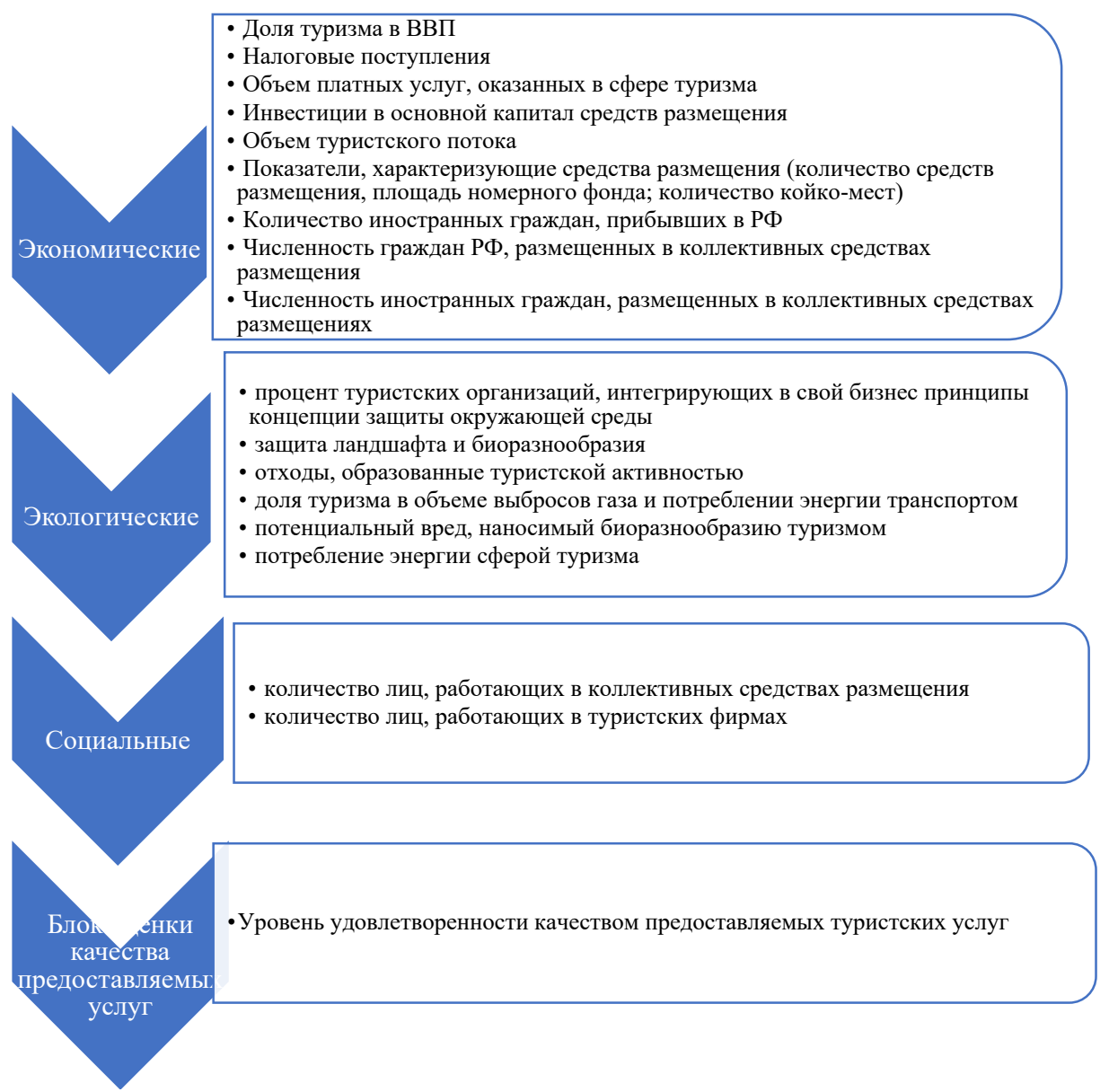

В настоящее время не проводится на должном уровне анализ и оценка экологической ситуации и состояния природных ресурсов, так же недостаточно исследуется туристский спрос, в том числе качество туристского продукта.

Развитие туристских организаций является результатом объединения трех основных факторов, а в целях повышения эффективности необходимо инвестировать средства в развитие дан- ных факторов (рис. 4.)

В таблице 3 представлена система сбалансированных показателей, которая может быть использована для анализа и оценки финансового состояния, конкурентных позиций на рынке, эффективности бизнес-процессов и системы оценки системы мотивации персонала туристских организаций во временном аспекте. человеческие ресурсы

информационные системы

организационные бизнеспроцессы
• повышение квалификации сотрудников

• внедрение современных информационных технологий

\section{- совершенствование внутри предприятия} организационной системы и бизнеспроцессов

Puc. 4. Факторы развития туристских организаций 


\section{Таблица 3. Система сбалансированных показателей для оценки деятельности турфирм}

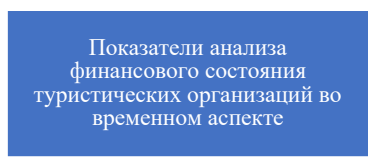

•Чистая прибыль за текущий год по сравнению с прошлым годом, выручка за текущий год по сравнению с прошлым годом, средняя цена акции в текущем месяце по сравнению с прошлым годом

• Коэффициент текущей

ликвидности

- Коэффициент обеспеченности

$\mathrm{COC}$

- Коэффициент финансовой

устойчивости

• Коэффициент концентрации

привлеченных средств

- Коэффициент EVA

(добавленная экономическая

стоимость)

• Коэффициент MVA

(добавленная рыночная

стоимость)

- Доля продаж зарубежных туров

в общем объеме продаж

-Уровень риска (вероятность

банкротства)
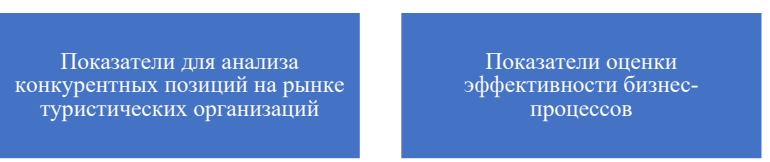

- Объем продаж. Рассчитывается как отношение объема продаж планируемого года к объему продаж предыдущего года.

- Количество заключенных договоров.

- Объем продаж за рубежом.

Рассчитывается как отношение

объема продаж зарубежных

туров к общему объему продаж.

- Уровень удовлетворенности

потребителя. Оценивается

количестве поступивших

жалоб.

-Перенос туров. Рассчитывается

как отношение перенесенных

туров к общему числу туров.

- Доля новых туров в общем

объеме продаж.

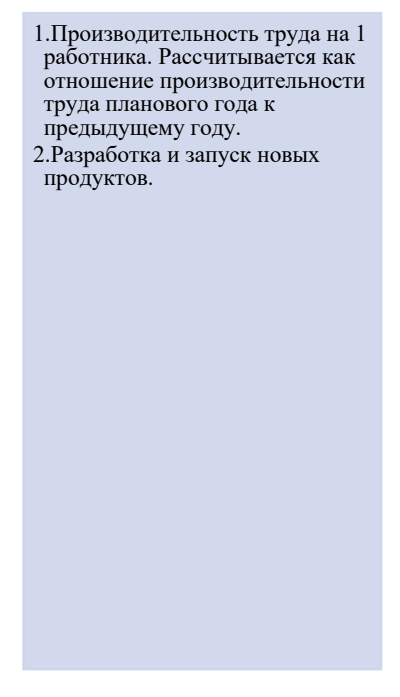

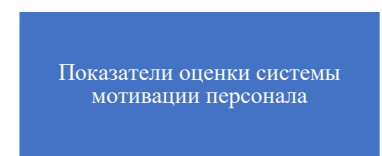

1.Количество часов обучения на 1 работника по

профессиональной

деятельности. Рассчитывается как отношение общего числ часов обучения к общей численности.

Процент охвата работников обучением по профессиональной деятельности. Рассчитывается как отношение общего числа обученныхработников к общей численности.

Фондоотдача информационных систем.Рассчитывается как отношение объема продаж к первоначальной стоимости информационных систем.

Эксплуатационные затраты на информационные системы.

Создание и внедрение системы мотивации персонала,

основанной на системе

сбалансированных показателей.

\section{Библиографический список}

1. Гизатуллина О.М. Система показателей для оценки туристической деятельности в РФ// Экономические науки. - 2021.- № 8

2. Статистика туризма: учебник / коллектив авторов; под ред. А. Ю. Александровой. - М.: Федеральное агентство по туризму, 2014. -464 с. 